\title{
Laju Deoksigenasi dan Laju Reaerasi Sungai Bedadung Segmen Desa Gumelar, Kabupaten Jember
}

\author{
Deoxigenation and Reaeration Rate of Bedadung River in Gumelar Village Segment, Jember Regency \\ Sri Wahyuningsih*, Elida Novita, Rizky Fathonah Imami \\ Program Studi Teknik Pertanian, Fakultas Teknologi Pertanian, Universitas Jember, \\ Jl. Kalimantan No. 37, Krajan Timur, Sumbersari, Kabupaten Jember 68121, Indonesia \\ *Email: sriwahyuningsih.ftp@unej.ac.id; rizkyfathonahimami@gmail.com
}

Tanggal submisi: 19 Desember 2018; Tanggal penerimaan: 27 Maret 2019

\begin{abstract}
ABSTRAK
Sungai Bedadung merupakan sungai utama di DAS Bedadung Kabupaten Jember. Masyarakat sekitar memanfaatkan sungai tersebut untuk memenuhi kebutuhan sehari-hari dan irigasi pertanian. Bahan pencemar organik dari limbah domestik dan limbah pertanian yang masuk ke sungai dapat menurunkan konsentrasi oksigen terlarut (DO) di sungai yang dapat mempengaruhi kualitas air sungai. Sungai mempunyai kemampuan untuk melakukan purifikasi alami dengan mekanisme deoksigenasi atau pengurangan oksigen dan reaerasi atau penambahan oksigen. Tujuan dalam penelitian ini yaitu untuk mengetahui laju deoksigenasi dan laju reaerasi menggunakan metode StreeterPhelps. Laju deoksigenasi dan laju reaerasi tersebut mempengaruhi perubahan konsentrasi oksigen terlarut pada perairan. Penelitian ini mengunakan data primer dengan mengambil sampel air sungai secara grab sampling pada 5 titik dan 4 segmen pemantauan. Hasil penelitian menunjukkan bahwa laju deoksigenasi adalah 0,036 $\mathrm{mg} / \mathrm{L}$.hari dan nilai laju reaerasi 0,046 mg/L.hari yang berarti bahwa laju pengurangan oksigen lebih kecil dari pada laju penambahan oksigen ke dalam air sungai sehingga proses purifikasi alami dapat berjalan dengan baik. Nilai konsentrasi DO rerata adalah 7,62 mg/L yang menunjukkan bahwa sungai masih berada di atas ambang batas baku mutu kualitas air sungai kelas III sehingga kualitas air sungai masih bagus dan aman digunakan oleh masyarakat. Selanjutnya hasil penelitian ini akan bermanfaat bagi penentuan daya dukung sungai.
\end{abstract}

Kata kunci: Laju deoksigenasi; laju reaerasi; Streeter-Phelps

\begin{abstract}
Bedadung River is the main river in the Bedadung Watershed in Jember Regency. People use the river to fulfill their daily needs and agricultural irrigation. Organic pollutants from domestic wastewater and agriculture wastewater that enter in river can decrease dissolved oxygen concentration, which can influence the river's water quality. The river has a self-purification system with a reaeration and deoxygenation mechanism. The purpose of this study was to analyze the rate of deoxygenation and reaeration using the Streeter-Phelps method. Deoxygenation and reaeration rates influence oxygen concentration. This research took water samples using a Grab Sampling technique as the primary data at 5 nodes and 4 segmentations. The results of the research showed that the deoxygenation rate was $0.036 \mathrm{mg} / \mathrm{L}$.day and the reaeration rate was $0.046 \mathrm{mg} / \mathrm{L}$.day. This meant that the deoxygenation rate was lower than the reaeration rate so the self-purification can run quite well. The average DO value was $7.62 \mathrm{mg} / \mathrm{L}$, showed that the river according to the class III water quality standard, so, the water quality was good and save to be used by the public. The research result can be used to determine the water quality carrying capacity in the next research.
\end{abstract}

Keywords: Deoxygenation rate; reaeration rate; Streeter-Phelps

DOI: http://doi.org/10.22146/agritech.41969

ISSN 0216-0455 (Print), ISSN 2527-3825 (Online) 


\section{PENDAHULUAN}

Sungai adalah alur atau wadah alami maupun buatan berupa jaringan pengaliran air mulai dari hulu pegunungan sampai bermuara ke danau atau laut dengan dibatasi oleh garis sempadan (Peraturan Pemerintah Republik Indonesia Nomor 38 Tahun 2011 tentang Sungai). Kualitas air sungai dipengaruhi oleh kualitas pasokan air yang berasal dari daerah tangkapan, sedangkan kualitas pasokan air dari daerah tangkapan berkaitan dengan aktivitas manusia yang ada di dalamnya (Wiwoho, 2005). Berbagai aktivitas manusia dalam memenuhi kebutuhan hidupnya yang berasal dari kegiatan industri, rumah tangga, dan pertanian akan menghasilkan limbah yang memberi sumbangan pada penurunan kualitas air sungai (Agustiningsih, 2012).

Sungai Bedadung merupakan sungai terbesar yang berada pada DAS Bedadung dan melintasi Kabupaten Jember dengan panjang 46.875 m (Santoso dkk., 2014). Salah satu wilayah yang dialiri Sungai Bedadung yaitu Desa Gumelar di Kecamatan Rambipuji dengan tata guna lahan sebagai daerah pemukiman, persawahan, perkebunan dan peternakan. Limbah dari kegiatan masyarakat yang dibuang maupun dialirkan ke dalam sungai secara terus-menerus dapat menurunkan kualitas air sehingga sungai tidak dapat digunakan sebagaimana peruntukannya. Berdasarkan Peraturan Pemerintah Republik Indonesia Nomor 38 Tahun 2011 tentang Sungai, sungai memiliki kemampuan sebagai pemulih kualitas air sehingga perlu dijaga dengan tidak membebani zat pencemar melebihi kemampuan pemulihan alami (purifikasi alami) air sungai tersebut.

Oksigen memegang peranan penting sebagai indikator kualitas perairan, karena oksigen terlarut berperan dalam proses oksidasi dan reduksi bahan organik dan anorganik (Salmin, 2005). Melalui proses oksidasi dan reduksi tersebut maka beban pencemaran pada perairan dapat berkurang secara alami. Selain itu, menurut Keputusan Menteri Negara Lingkungan Hidup Nomor 110 Tahun 2003 tentang Pedoman Penetapan Daya Tampung Beban Pencemaran Air pada Sumber Air, metode pemodelan Streeter-Phelps dapat digunakan untuk mengukur daya tampung sungai dengan mempertimbangkan kebutuhan oksigen pada kehidupan air (BOD) dan ditentukan atas dasar defisit oksigen terlarut (DO). Metode Streeter-Phelps dipengaruhi oleh dua fenomena yaitu proses pengurangan oksigen terlarut (deoksigenasi) akibat aktivitas bakteri dalam menguraikan bahan organik dalam air (dekomposisi bahan organik) serta proses peningkatan oksigen terlarut (reaerasi) yang disebabkan oleh turbulensi aliran sungai (Arbie dkk., 2015).

Penggunaan metode Streeter-Phelps akan menghasilkan kurva defisit oksigen yang menggambarkan kemampuan sungai untuk melakukan purifikasi alami. Kurva defisit oksigen tersebut dipengaruhi oleh laju deoksigenasi dan laju reaerasi. Laju deoksigenasi menunjukkan kecepatan penggunaan oksigen untuk proses dekomposisi dan laju reaerasi menunjukkan kecepatan penambahan oksigen akibat adanya turbulensi aliran air per satuan hari. Dengan demikian, perlu adanya analisis laju proses deoksigenasi dan reaerasi Sungai Bedadung segmen Desa Gumelar guna mengetahui kemampuan sungai untuk melakukan purifikasi alami.

\section{METODE PENELITIAN}

\section{Penentuan Titik Penelitian}

Sungai Bedadung segmen Desa Gumelar sebagai wilayah kajian penelitian memiliki panjang $2.181 \mathrm{~m}$ yang dibagi menjadi 5 titik dengan 4 segmen, peta lokasi disajikan pada Gambar 1.

Pembagian titik dan segmen dilakukan berdasarkan potensi buangan limbah yang masuk ke dalam sungai seperti disajikan pada Gambar 2. Hal ini disebabkan karena mayoritas bahan pencemar yang masuk ke dalam sungai merupakan limpasan dari daerah pemukiman penduduk atau domestik serta daerah pertanian yang menyebar (non-point source). Selain itu, penentuan titik didasarkan pada metode Purposive Sampling yaitu pengambilan sampel berdasarkan titik yang diasumsikan dapat mewakili populasi penelitian, serta adanya kemudahan akses (Mahyudin dkk., 2015).

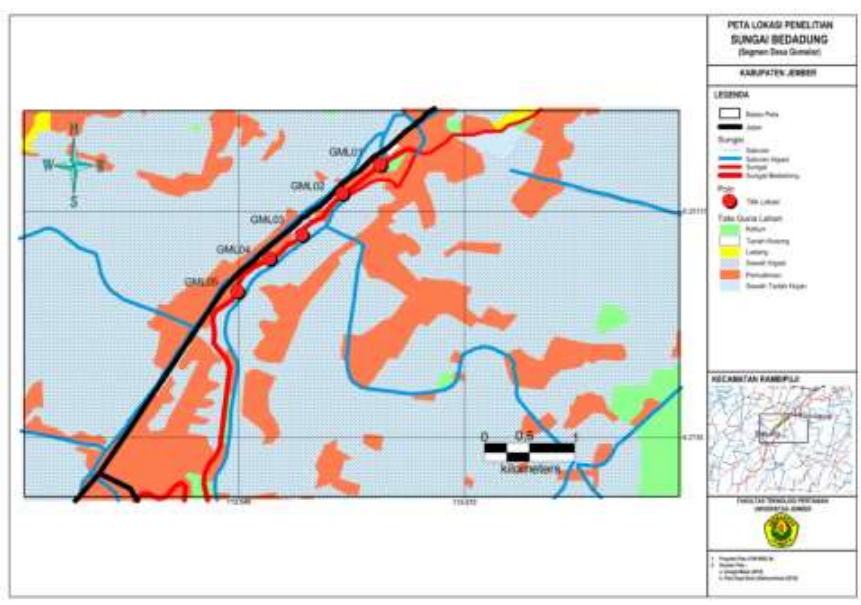

Gambar 1. Peta lokasi lokasi penelitian Sungai Bedadung segmen Desa Gumelar 


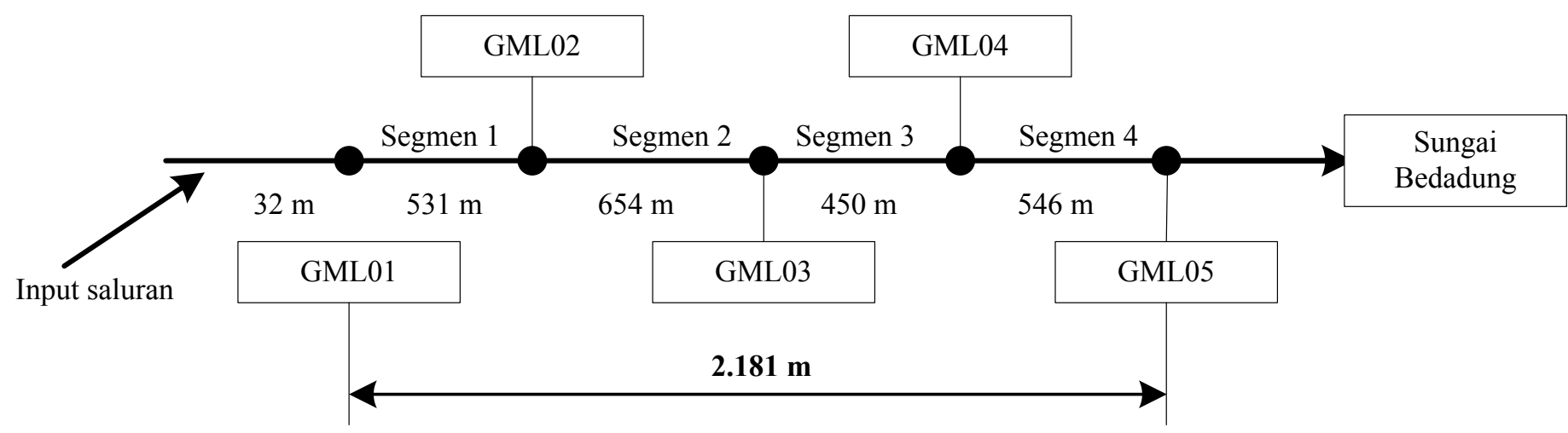

Gambar 2. Pembagian titik pada lokasi penelitian

Tabel 1. Titik lokasi penelitian di Sungai Bedadung

\begin{tabular}{|c|c|c|c|c|}
\hline \multirow{2}{*}{ Desa } & \multirow{2}{*}{ Segmen } & \multirow{2}{*}{ Titik Lokasi } & \multicolumn{2}{|c|}{ Koordinat Titik Lokasi } \\
\hline & & & ${ }^{\circ} \mathrm{BT}$ & ㄴS \\
\hline \multirow{6}{*}{ Gumelar } & & GML01 & 113,5631333 & $-8,24679930$ \\
\hline & & GML02 & 113,5592945 & $-8,24964083$ \\
\hline & Segmen 2 & GMI 03 & 1135552423 & -825373087 \\
\hline & Segmen 3 & & & \\
\hline & & GML04 & 113,5520123 & $-8,25611764$ \\
\hline & & GML05 & 113,5487740 & $-8,25938480$ \\
\hline
\end{tabular}

${ }^{*}$ GML adalah singkatan dari Gumelar (desa lokasi penelitian)

\section{Pengukuran Kualitas Air}

Kualitas air Sungai Bedadung segmen Desa Gumelar selama ini belum ditetapkan sehingga perlu adanya analisis terhadap kriteria kelas mutu air sungai. Berdasarkan Peraturan Menteri Negara Lingkungan Hidup Nomor 01 Tahun 2010 tentang Tata Laksana Pengendalian Air, sungai yang belum ditetapkan kelas mutunya dapat menjadikan kriteria kualitas air kelas II pada Peraturan Pemerintah Nomor 82 Tahun 2001 tentang Pengelolaan Kualitas Air dan Pengendalian Pencemaran Air sebagai acuan. Pengambilan data kualitas air per parameter dilakukan sebanyak 3 kali dengan selisih satu hari untuk setiap pengambilan. Sedangkan, pengambilan sampel air dari sungai dengan metode Grab Sampling menggunakan botol sampel dan diawetkan dengan menempatkannya pada cool box bersuhu $\pm 4^{\circ} \mathrm{C}$ (Alaerts dan Santika, 1984). Kemudian, dilakukan analisis parameter kualitas di Laboratorium Teknik Pengendalian dan Konservasi Lingkungan Jurusan Teknik Pertanian, Fakultas Teknologi Pertanian, Universitas Jember (Tabel 2).

\section{Pengukuran Karakteristik Sungai}

Pengukuran karakteristik sungai meliputi pengukuran dimensi sungai, pengukuran kecepatan aliran sungai, dan pengukuran debit aliran sungai. Pengukuran dimensi sungai dilakukan dengan terlebih dahulu membagi lebar sungai menjadi 6 pias dan lebar pias tersebut memiliki interval jarak yang sama tersaji pada Gambar 3. Kemudian, dilakukan pengukuran kedalaman sungai sehingga didapatkan luas penampang (A) atau cross section dari hasil perkalian kedalaman $(\mathrm{H})$ dan lebar ( $L$ ) sungai tersebut. Pengukuran kedalaman

Tabel 2. Metode analisis parameter kualitas air

\begin{tabular}{llll}
\hline No & Parameter Kualitas Air & Metode & Standar \\
\hline 1 & TSS (Total Suspended Solid) & Gravimetri & SNI 06-6989.3 2004 \\
2 & TDS (Total Dissolved Solid) & TDS Meter & - \\
3 & Kekeruhan & Turbidity Meter/ Nefelometer & SNI 06-6989.25 2005 \\
4 & pH (Power of Hydrogen) & pH Meter & SNI 06-6989.11 2004 \\
5 & DO (Dissolved Oxygen) & Iodometri/ Titrasi Winkler & SNI 06-6989.14 2004 \\
6 & BOD (Biological Oxygen Demand) & Iodometri/ Titrasi Winkler & SNI 06-6989.14 2004 \\
\hline
\end{tabular}


dan lebar sungai menggunakan tongkat, tali tambang, dan roll meter.

Luas penampang (A) pada masing-masing pias dihitung dengan Persamaan 1.

$$
A n=\frac{H(n-1)+H n}{2} \times L n
$$

dengan S: permukaan sungai, dan B: dasar sungai, $\mathrm{H}$ : kedalaman $(m)$, L: lebar interval $(m)$, dan A: luas penampang $\left(m^{2}\right)$.

Pengambilan data kecepatan aliran dan debit dilakukan sebanyak 3 kali dengan selisih satu hari untuk setiap pengambilan. Pengukuran kecepatan (V) aliran sungai menggunakan current meter dilakukan pada masing-masing pias dan menghasilkan data berupa jumlah putaran baling-baling per satuan waktu. Langkah-langkah pengukuran kecepatan aliran yang dilakukan sebagaimana telah ditetapkan dalam SNI 8066:2015 dengan range waktu yang ditentukan yaitu 10 detik. Perhitungan kecepatan aliran disesuaikan dengan current meter menggunakan Persamaan 2 (Triatmodjo, 2013).

$V=a N+b$

dengan a dan b: konstanta current meter menurut tipe alat, serta $\mathrm{N}$ jumlah putaran baling-baling (putaran/detik).

Kedalaman pengukuran dan perhitungan kecepatan aliran dapat ditentukan seperti pada Tabel 3 (Rahayu dkk., 2009). Pengukuran debit (Q) aliran sungai merupakan pengukuran terhadap jumlah air yang mengalir di dalam saluran per unit waktu ( $\mathrm{m}^{3} /$ detik). Total debit aliran sungai pada setiap penampang dapat dihitung dengan Persamaan 3 (Rahayu dkk., 2009).

$$
Q=A \times V=A_{1} V_{1}+A_{2} V_{2}+\ldots . . A_{n} V_{n}
$$

\section{Perhitungan DO menggunakan Metode Streeter- Phelps}

Perhitungan DO menggunakan Metode StreeterPhelps terdiri dari tahap pemodelan BOD, penentuan laju deoksigenasi dan laju reaerasi serta pembuatan

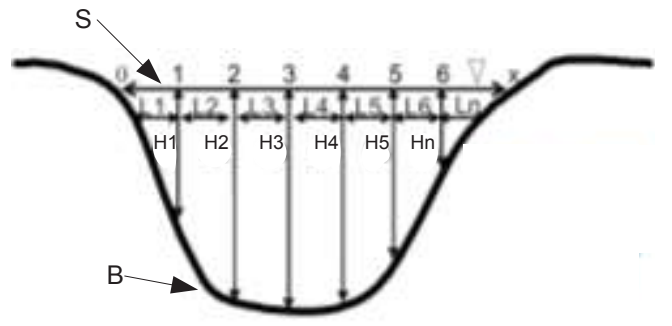

Gambar 3. Pembagian lebar pias penampang sungai (Rahayu dkk., 2009)
Tabel 3. Penentuan kedalaman pengukuran dan perhitungan kecepatan aliran

\begin{tabular}{lll}
\hline $\begin{array}{l}\text { Kedalaman } \\
\text { air }(\mathrm{m})\end{array}$ & $\begin{array}{l}\text { Kedalaman } \\
\text { pengukuran }\end{array}$ & $\begin{array}{l}\text { Perhitungan V rata-rata } \\
(\mathrm{m} / \text { detik) }\end{array}$ \\
\hline $0-0,6$ & $0,6 \mathrm{H}$ & $\mathrm{V}=\mathrm{V} 0,6$ \\
$0,6-3,0$ & $0,2 \mathrm{H}$ dan $0,8 \mathrm{H}$ & $\mathrm{V}=0,5(\mathrm{~V} 0,2+\mathrm{V} 0,8)$ \\
$3,0-0,6$ & $0,2 \mathrm{H} ; 0,6 \mathrm{H}$ dan & $\mathrm{V}=0,25(\mathrm{~V} 0,2+\mathrm{V} 0,6+\mathrm{V} 0,8)$ \\
& $0,8 \mathrm{H}$ & \\
$>6$ & $\mathrm{~S}, 0,2 \mathrm{H} ; 0,6 \mathrm{H} ;$ & $\begin{array}{l}\mathrm{V}=0,1\left(\mathrm{~V}_{\mathrm{S}}+3 \mathrm{~V} 0,2+2 \mathrm{~V} 0,6\right. \\
\left.\text { 3 } 0,8+\mathrm{V}_{\mathrm{B}}\right)\end{array}$ \\
\hline
\end{tabular}

kurva defisit oksigen. Pemodelan bertujuan untuk mendapatkan informasi kontribusi beban pencemaran khususnya parameter BOD (bahan pencemar organik). Laju oksidasi biokimia senyawa organik ditentukan oleh konsentrasi senyawa organik sisa (residu) ditentukan pada Persamaan 4 (Streeter dan Phelps, 1952).

$$
\frac{d L}{d t}=-K d x L
$$

dengan L: konsentrasi senyawa organik (mg/L), t: waktu (hari), dan Kd: konstanta deoksigenasi (hari $\left.{ }^{-1}\right)$.

Apabila konsentrasi awal senyawa organik sebagai BOD adalah $\mathrm{L}_{0}$ yang dinyatakan sebagai BOD ultimate (total) dan Lt adalah BOD residual pada saat waktu tertentu $(\mathrm{t})$ maka hasil integrasi pertama selama masa oksidasi seperti pada Persamaan 4.

$$
L t=L_{0} e^{(-K d . t)}
$$

dengan Lt: BOD residu (mg/L), Lo: BOD ultimate $(\mathrm{mg} / \mathrm{L})$, e: 2,178, Kd: konstanta deoksigenasi (hari-1), t: 5 (waktu inkubasi untuk $\mathrm{BOD}_{5}^{20}$ ).

Berdasarkan Keputusan Menteri Lingkungan Hidup Nomor 110 Tahun 2003 tentang Pedoman Penetapan Daya Tampung Beban Pencemaran Air pada Sumber Air, nilai $\mathrm{L}_{0}$ didapatkan dari Persamaan 6.

$$
L_{0}=\frac{B O D_{5}}{\left(1-e^{K d . t}\right)}
$$

Proses pengurangan oksigen atau deoksigenasi dalam air diakibatkan proses biokimia yang ditentukan dari laju deoksigenasi. Laju deoksigenasi (rD) akibat senyawa organik didapatkan dengan Persamaan 7.

$$
r D=K d_{T} \times L t=K d(1,047)^{T-20} \times L t
$$
dengan $\mathrm{Kd}_{\mathrm{T}}$ : konstanta deoksigenasi pada suhu tertentu (hari-1). 
Nilai Kd (konstanta dekomposisi atau deoksigenasi bahan organik) dapat ditentukan menggunakan metode Hydroscience seperti pada Persamaan 8 (Ramadhani, 2013).

$$
K d=0,3 \times\left(\frac{H}{8}\right)^{-0,434}
$$

dengan $\mathrm{Kd}$ : konstanta deoksigenasi (hari-1) dan $\mathrm{H}$ : kedalaman air (m).

Berdasarkan Keputusan Menteri Negara Lingkungan Hidup Nomor 110 Tahun 2003 tentang Pedoman Penetapan Daya Tampung Beban Pencemaran Air pada Sumber Air, proses reaerasi merupakan proses perpindahan oksigen dari udara ke air. Kecepatan peralihan (transfer) oksigen tersebut dinyatakan dengan laju reaerasi (rR) Peraturan Pemerintah Republik Indonesia, 2001.

$\left.r R=K r_{T} \times D=\left(K r(1,016)^{T-20}\right) \times\left(D O_{s}-D O_{a c t}\right)\right)$

Nilai $\mathrm{Kr}$ didapatkan dari persamaan O'Connor dan Dobbins (Percamaan 10 )

$K r=\frac{294\left(D_{L T} \times V\right)^{1 / 2}}{H^{3 / 2}}=\frac{294\left(\left(1,760 \times 10^{-4} \times(1,037)^{T-20}\right) \times V\right)^{1 / 2}}{H^{2 / 3}}$.

dengan $\mathrm{Kr}$ : konstanta reaerasi (hari $\left.{ }^{-1}\right)$, D: defisit oksigen terlarut (mg/L), DO : oksigen terlarut jenuh (mg/L), DO : oksigen terlarut sungai $(\mathrm{mg} / \mathrm{L})$, T: suhu air sungai $\left({ }^{\circ} \mathrm{C}\right)$, V: kecepatan aliran $\left(\mathrm{m}^{2} / \mathrm{s}\right)$, $\mathrm{H}$ : kedalaman aliran $(\mathrm{m}), \mathrm{D}_{\mathrm{LT}}$ : koefisien difusi molekular oksigen pada suhu tertentu ( $\mathrm{m}^{2} /$ hari), dan 1,76 x 10-4: koefisien difusi molekular oksigen pada suhu $20^{\circ} \mathrm{C}$.

\section{Bahan}

Bahan yang digunakan dalam penelitian yaitu sampel air sungai, Aquades, larutan Mangan Sulfat (MnSO4), Alkali-iodida Azida, Asam Sulfat pekat (H2SO4), Natrium Tiosulfat (Na2S2O3), indikator Amilum, tisu, dan kertas filter diameter pori $0,45 \mu \mathrm{m}$.

\section{Alat}

Alat yang digunakan dalam penelitian yaitu GPS (Global Positioning System), kamera digital, pasak, tali tambang, roll meter, SEBA F394 current meter, stopwatch, kalkulator, termometer, botol sampel, cool box, cawan, neraca analitik OHAUS, penjepit, nampan, oven, desikator, gelas ukur, corong penyaring, KL139 TDS meter, Eutech TN-100 turbidity meter, Senz $\mathrm{pH}$ meter, botol semprot, botol Winkler, gelas beker, erlenmeyer, pipet suntik, pipet volumentrik, bola hisap, buret, dan lemari es.

\section{HASIL DAN PEMBAHASAN}

\section{Kualitas Air Sungai Bedadung}

Analisis kualitas air Sungai Bedadung dilakukan di laboratorium seperti disajikan pada Gambar 4. Hasil analisis menunjukkan bahwa nilai parameter TDS, $\mathrm{pH}, \mathrm{DO}$, dan BOD memenuhi kriteria mutu air kelas II, sedangkan nilai paramater TSS masuk ke dalam kriteria mutu air kelas III sebagaimana ketentuan pada Peraturan Pemerintah Nomor 82 Tahun 2001 tentang Pengelolaan Kualitas Air dan Pengendalian Pencemaran Air. Dengan demikian, parameter kualitas air Sungai Bedadung berada pada kriteria mutu air kelas III. Kriteria mutu air tersebut juga didukung dengan nilai TSS yang tinggi sehingga menyebabkan air keruh. Selain itu, terdapat peternakan di wilayah kajian GML03 yang membuang langsung limbahnya ke dalam sungai sehingga air berbau ditunjukkan pada Gambar 5.

Berdasarkan mutu air kelas III maka Sungai Bedadung sebagaimana peruntukannya dapat digunakan untuk pembudidayaan ikan air tawar, peternakan, air untuk mengairi pertanaman, dan atau peruntukan lain yang mempersyaratkan mutu air yang sama dengan

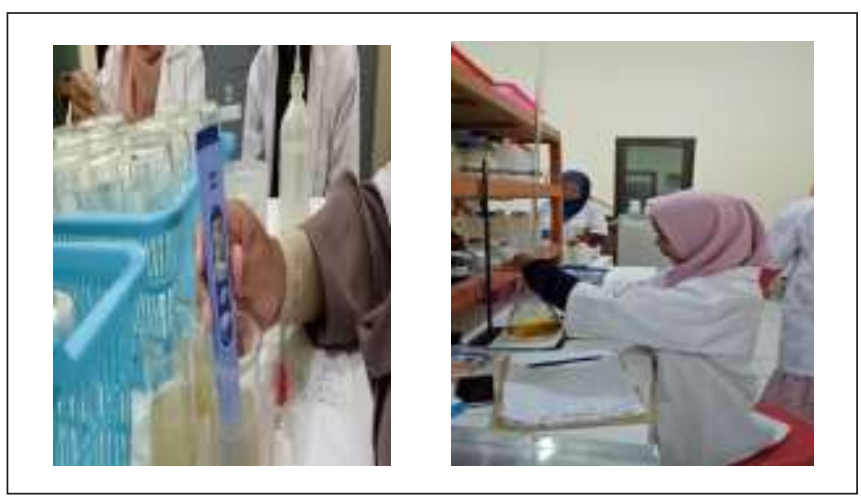

Gambar 4. Analisis kualitas air di laboratorium

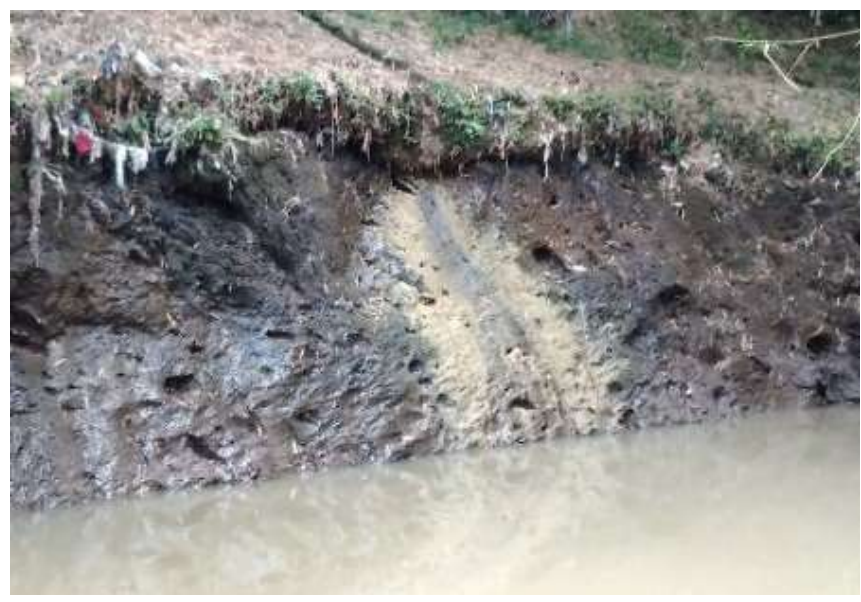

Gambar 5. Limpasan peternakan ayam di GML03 
Tabel 4. Data kualitas air Sungai Bedadung

\begin{tabular}{|c|c|c|c|c|c|c|c|c|c|}
\hline \multirow[t]{2}{*}{ Parameter } & \multirow[t]{2}{*}{ Satuan } & \multicolumn{5}{|c|}{ Titik Lokasi } & \multirow{2}{*}{$\begin{array}{l}\text { Rata-rata } \\
\text { Kualitas Air }\end{array}$} & \multicolumn{2}{|c|}{$\begin{array}{c}\text { Kriteria Mutu Air } \\
\text { Kelas*) }\end{array}$} \\
\hline & & GML01 & GML02 & GML03 & GML04 & GML05 & & $\left.\mathrm{II}^{* *}\right)$ & III \\
\hline TSS & $\mathrm{mg} / \mathrm{L}$ & 169,19 & 126,07 & 147,11 & 160,52 & 170,67 & 154,71 & 50 & 400 \\
\hline TDS & $\mathrm{mg} / \mathrm{L}$ & 98,11 & 99,44 & 100,67 & 101,44 & 103,33 & 100,60 & 1000 & 1000 \\
\hline Kekeruhan & NTU & 54,31 & 44,84 & 44,36 & 45,12 & 43,37 & 46,40 & & \\
\hline $\mathrm{pH}$ & & 7,78 & 7,80 & 7,79 & 7,74 & 7,76 & 7,77 & $6-9$ & $6-9$ \\
\hline DO & $\mathrm{mg} / \mathrm{L}$ & 7,69 & 7,65 & 7,70 & 7,52 & 7,56 & 7,62 & 4 & 3 \\
\hline BOD & $\mathrm{mg} / \mathrm{L}$ & 1,54 & 1,26 & 1,34 & 1,41 & 1,52 & 1,41 & 3 & 6 \\
\hline
\end{tabular}

*) Sumber: Peraturan Pemerintah Republik Indonesia Nomor 82 Tahun 2001 tentang Pengelolaan Kualitas Air dan Pengendalian Pencemaran Air $\left.{ }^{* *}\right)$ Kriteria mutu air kelas II sebagai acuan

kegunaan tersebut. Hasil analisis terhadap nilai ratarata parameter kualitas air Sungai Bedadung tersaji pada Tabel 4.

\section{Karakteristik Sungai Bedadung}

Analisis karakteristik sungai meliputi pengukuran dimensi sungai untuk mengetahui luas penampang sungai dan pengukuran kecepatan aliran sungai yang akan digunakan untuk pengukuran debit aliran sungai. Pengukuran debit aliran sungai akan berpengaruh pada nilai kecepatan reaksi. Hasil pengukuran debit disajikan pada Tabel 5 yang menunjukkan bahwa Sungai Bedadung memiliki nilai debit yang fluktuatif. Debit sungai tertinggi berada pada GML02 yaitu 5,889 $\mathrm{m}^{3} /$ detik. Sedangkan, debit sungai terendah berada pada GML05 yaitu $4,112 \mathrm{~m}^{3} /$ detik. Perbedaan nilai debit pada setiap titik dipengaruhi oleh luas penampang (A) dan kecepatan (V) aliran sungai. Semakin besar luas penampang dan kecepatan aliran maka debit yang dihasilkan semakin besar, begitu pun sebaliknya (Rahayu ., 2009). Kondisi sungai yang berkelok dan dasar sungai yang tidak rata mempengaruhi kecepatan aliran sehingga nilai

Tabel 5. Data debit air Sungai Bedadung

\begin{tabular}{lllll}
\hline \multirow{2}{*}{ Titik } & \multicolumn{3}{c}{ Debit $\left(\mathrm{m}^{3} /\right.$ detik $)$} & \multirow{2}{*}{ Rata-rata } \\
\cline { 2 - 4 } & $\mathrm{P} 1$ & $\mathrm{P} 2$ & $\mathrm{P3}$ & \\
\hline GML01 & 5,989 & 5,249 & 5,366 & 5,534 \\
GML02 & 6,102 & 5,690 & 5,874 & 5,889 \\
GML03 & 4,913 & 4,647 & 4,794 & 4,785 \\
GML04 & 5,603 & 4,948 & 4,966 & 5,172 \\
GML05 & 3,923 & 4,157 & 4,256 & 4,112 \\
Rata-rata & 5,098 & & & \\
\hline
\end{tabular}

*) $\mathrm{P}=$ Pengambilan ke- kecepatan yang dihasilkan dan terbaca di current meter tidak konstan.

\section{Konstanta Deoksigenasi (Kd) dan Konstanta Reaerasi (Kr)}

Hasil perhitungan nilai konstanta deoksigenasi (Kd) dan konstanta reaerasi ( $\mathrm{Kr}$ ) disajikan pada Tabel 6. Kd adalah konstanta dekomposisi untuk mengetahui konsentrasi BOD atau materi organik yang terdekomposisi terhadap waktu. Nilai Kd menunjukkan besarnya laju penguraian bahan organik oleh mikroorganisme aerob dalam perairan (Fachrul ., 2011). Nilai Kd Sungai Bedadung berkisar antara 0,657 hari-1 hingga 0,877 hari- $^{-1}$ dengan rata-rata yaitu 0,766 hari 1. Kd tertinggi terdapat di GML04 karena proses difusi oksigen dari atmosfer berlangsung cepat sehingga proses dekomposisi bahan organik berjalan cepat. Dekomposisi biologi materi organik pada badan sungai tergantung pada kondisi dinamis lingkungan sekitar sungai, jenis mikroorganisme yang ada dalam badan air, serta jumlah mikroorganisme itu sendiri (Arbie dkk., 2015).

Kr adalah konstanta reaerasi yang menunjukkan peningkatan oksigen terlarut yang terjadi akibat turbulensi aliran air pada sungai. Nilai Kr Sungai Bedadung berkisar antara 1,653 hari $^{-1}$ hingga 5,104 hari-1 $^{-1}$ dengan rata-rata yaitu 3,245 hari-1. GML04 memiliki nilai $\mathrm{Kr}$ tertinggi yang disebabkan karena titik lokasi tersebut memiliki kedalaman paling dangkal dan kecepatan tertinggi. Pada kecepatan yang tinggi dan kedalaman yang rendah, nilai $\mathrm{Kr}$ menjadi tinggi bagitupun sebaliknya (Fachrul dkk., 2011).

Hubungan antara $\mathrm{Kd}$ dan $\mathrm{Kr}$ disajikan pada Gambar 6 memiliki pola yang sama. Semakin besar Kd dan $\mathrm{Kr}$ maka akan semakin besar pula potensi sungai untuk menyediakan oksigen terlarut dari atmosfer dan semakin besar pula potensinya untuk melakukan 
Tabel 6. Data perhitungan konstanta deoksigenasi dan konstanta reaerasi

\begin{tabular}{llllllllllll}
\hline \multirow{2}{*}{ Titik } & $\mathrm{DO}$ & $\mathrm{BOD}$ & $\mathrm{H}$ & $\mathrm{T}$ & $\mathrm{Kd}$ & $\mathrm{KdT}$ & $\mathrm{Kr}$ & $\mathrm{KrT}$ & $\mathrm{Lo}$ & $\mathrm{Lt}$ & $\mathrm{D}$ \\
\cline { 2 - 11 } & $\mathrm{mg} / \mathrm{L}$ & $\mathrm{mg} / \mathrm{L}$ & $\mathrm{m}$ & ${ }^{\circ} \mathrm{C}$ & hari $^{-1}$ & hari $^{-1}$ & hari $^{-1}$ & hari $^{-1}$ & $\mathrm{mg} / \mathrm{L}$ & $\mathrm{mg} / \mathrm{L}$ & $\mathrm{mg} / \mathrm{L}$ \\
\hline GML01 & 7,695 & 1,54 & 1,08 & 27,7 & 0,716 & 1,018 & 2,443 & 2,760 & 1,582 & 0,044 & 0,179 \\
GML02 & 7,647 & 1,26 & 1,31 & 27,9 & 0,657 & 0,946 & 1,653 & 1,875 & 1,304 & 0,049 & 0,188 \\
GML03 & 7,705 & 1,34 & 0,83 & 28,8 & 0,802 & 1,204 & 3,705 & 4,263 & 1,361 & 0,025 & 0,009 \\
GML04 & 7,518 & 1,41 & 0,68 & 29,0 & 0,877 & 1,326 & 5,104 & 5,888 & 1,428 & 0,018 & 0,173 \\
GML05 & 7,556 & 1,52 & 0,90 & 29,3 & 0,776 & 1,188 & 3,322 & 3,849 & 1,550 & 0,032 & 0,098 \\
Rata-rata & 7,624 & 1,41 & 0,96 & 28,5 & 0,766 & 1,136 & 3,245 & 3,727 & 1,445 & 0,034 & 0,129 \\
\hline
\end{tabular}

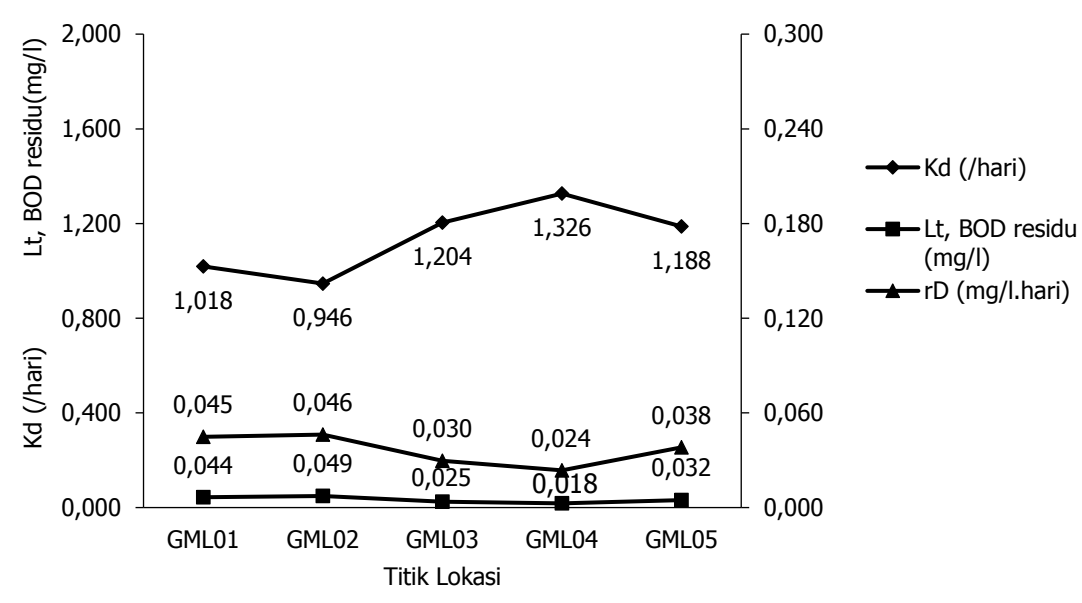

Gambar 6. Nilai Kd dan $\mathrm{Kr}$

dekomposisi, oksidasi, dan purifikasi secara alamiah (Razif, 1994). Fluktuatifnya nilai Kd dan Kr di sepanjang lokasi penelitian dapat disebabkan karena pengaruh lingkungan. Faktor lingkungan tersebut diantaranya kecepatan aliran, debit sungai, perubahan jumlah limbah yang masuk ke sungai, dan perubahan suhu.

\section{Laju Deoksigenasi dan Laju Reaerasi Sungai Bedadung}

Deoksigenasi merupakan proses pengurangan oksigen terlarut akibat aktivitas bakteri dalam menguraikan bahan organik dalam air. Sedangkan, reaerasi merupakan proses peningkatan oksigen terlarut yang disebabkan oleh turbulensi aliran sungai

Hasil perhitungan laju deoksigenasi dan laju reaerasi Sungai Bedadung disajikan pada Tabel 7. Laju deoksigenasi (rD) menunjukkan kecepatan penggunaan oksigen terlarut untuk proses biokimia seperti dekomposisi bahan organik (BOD), oksidasi, dan purifikasi. Secara teoritis, laju deoksigenasi dipengaruhi oleh konstanta deoksigenasi terhadap suhu (KdT) dan BOD residu (Lt). Berdasarkan metode Hydroscience, nilai konstanta deoksigenasi pada perairan dipengaruhi oleh kedalaman $(\mathrm{H})$ (Persamaan 8 ). Sedangkan, nilai
BOD residu menunjukkan sisa konsentrasi oksigen terlarut yang telah digunakan untuk mendegradasi bahan organik dalam suatu perairan. Hasil perhitungan konstanta deoksigenasi (KdT), BOD residu (Lt), dan laju deoksigenasi (rD) Sungai Bedadung disajikan pada Gambar 7.

Gambar 7 menunjukkan bahwa nilai laju deoksigenasi tertinggi pada GML02 yaitu 0,046 mg/L. hari dan laju deoksigenasi terendah pada GML04 yaitu 0,024 mg/L.hari. GML02 memiliki laju deoksigenasi

Tabel 7. Data laju deoksigenasi dan reaerasi Sungai Bedadung

\begin{tabular}{ccc}
\hline \multirow{2}{*}{ Titik } & rD & rR \\
\cline { 2 - 3 } & mg/L.hari & mg/L.hari \\
\hline GML01 & 0,045 & 0,494 \\
GML02 & 0,046 & 0,352 \\
GML03 & 0,030 & 0,038 \\
GML04 & 0,024 & 1,019 \\
GML05 & 0,038 & 0,377 \\
\hline
\end{tabular}

Rata-rata

0,036 


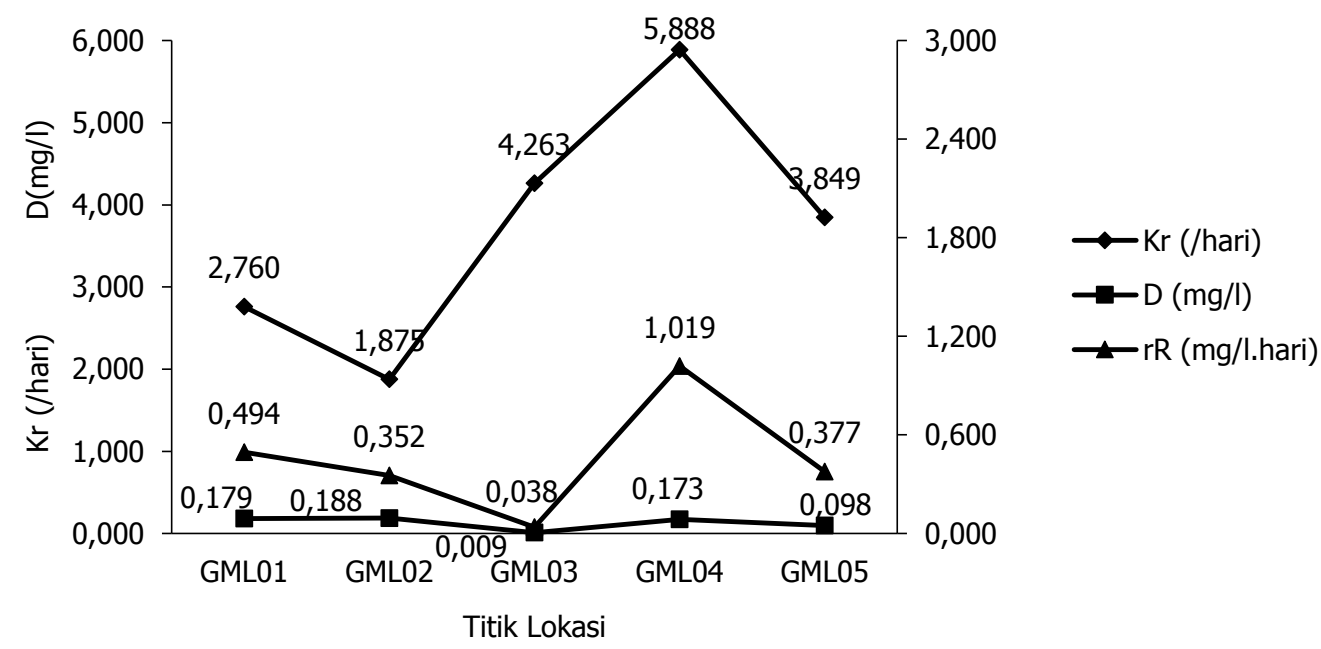

Gambar 7. Laju deoksigenasi (rD)

tertinggi disebabkan tingginya konsentrasi BOD residu dalam perairan yaitu 0,049 mg/L. Sedangkan, GML04 memiliki laju deoksigenasi terendah disebabkan oleh konsentrasi bahan organik dalam perairan yang paling rendah yaitu 0,018 $\mathrm{mg} / \mathrm{L}$. Konsentrasi BOD residu pada sungai dipengaruhi oleh profil dasar sungai yang tidak rata dan dipenuhi bebatuan serta kerikil sehingga terjadi turbulensi dan mempercepat proses penambahan oksigen (reaerasi). Rendahnya nilai BOD residu pada perairan dapat mengindikasi bahwa mikroba mampu melakukan dekomposisi dengan baik karena tingginya konsentrasi oksigen yang tersedia sebagaimana pada GML04. Kondisi sungai dari GML04 ditunjukkan pada Gambar 8.

Laju reaerasi (rR) menunjukkan kecepatan berdifusinya gas oksigen ke badan air akibat faktor

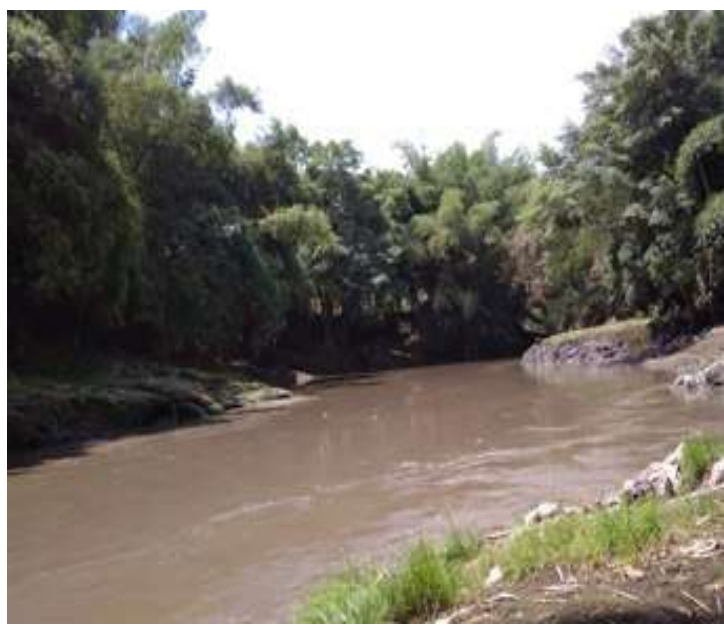

(a) hidrolik. Secara teoritis, laju reaerasi dipengaruhi oleh konstanta reaerasi terhadap suhu (KrT) yang menunjukkan kecepatan pengambilan oksigen oleh sungai dari atmosfir dan defisit oksigen terlarut (D). Semakin besar konstanta reaerasi maka semakin banyak oksigen yang masuk ke dalam air sungai dan menyebabkan konsentrasi oksigen terlarut (DO) meningkat serta menghindari terjadinya defisit oksigen yang berlebihan (Razif, 1994). Konstanta reaerasi merupakan fungsi kecepatan aliran sungai (V) dan kedalaman $(\mathrm{H})$ (Persamaan 10). Semakin besar kecepatan aliran dan semakin dangkalnya sungai maka konstanta reaerasi semakin besar, begitu pun sebaliknya. Sedangkan, defisit oksigen terlarut perairan bergantung pada oksigen terlarut jenuh (DO saturasi) akibat perubahan suhu dan oksigen terlarut aktual $\left(\mathrm{DO}_{a}\right)$ atau DO lapang pada perairan akibat intensitas terjadinya

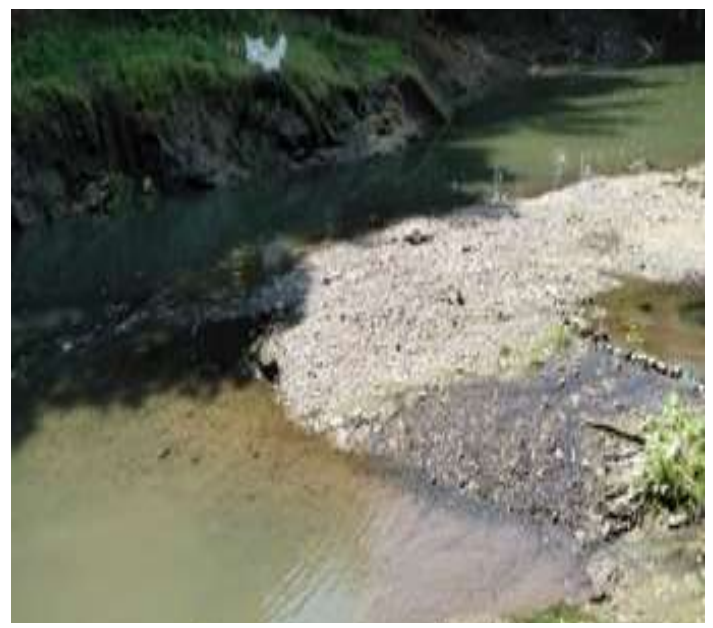

(b)

Gambar 8. Kondisi GML04 a) Kondisi ketika musim penghujan; (b) Kondisi ketika musim kemarau 


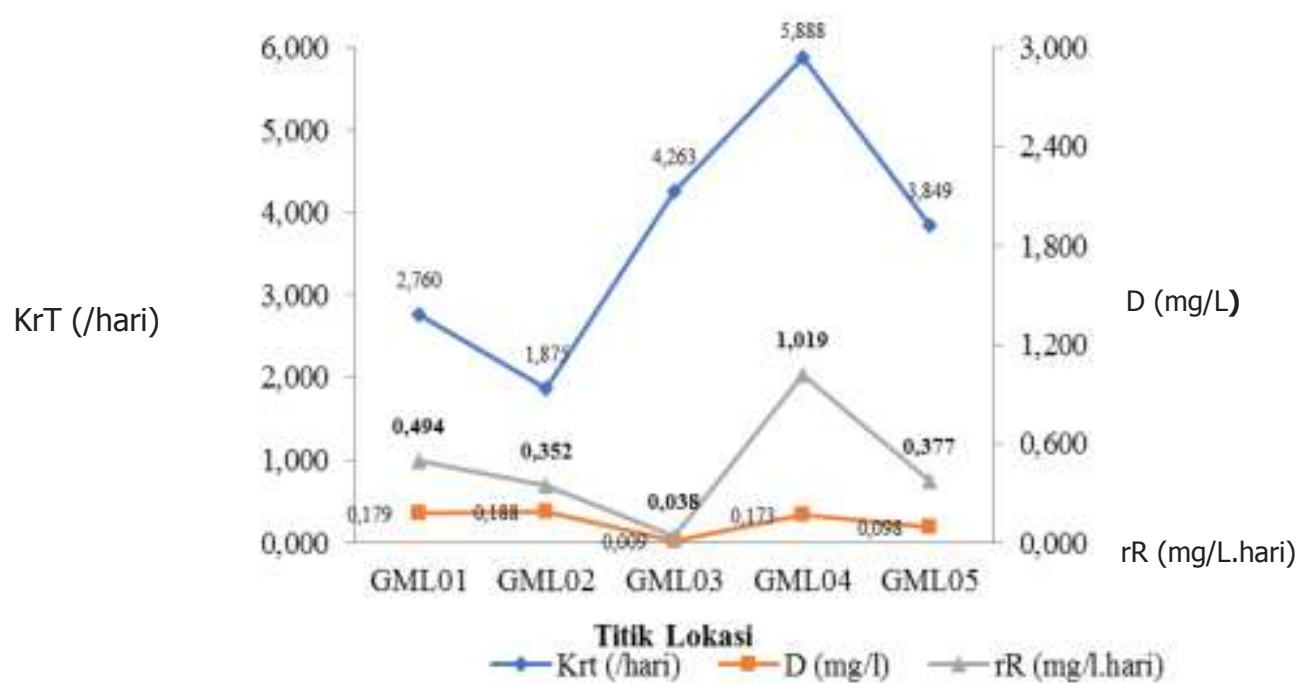

Gambar 9. Laju Reaerasi (rR)

turbulensi. Hasil perhitungan konstanta reaerasi $(\mathrm{KrT})$, defisit oksigen terlarut (D), dan laju reaerasi (rR) Sungai Bedadung disajikan Gambar 9.

Gambar 9 menunjukkan bahwa Laju reaerasi tertinggi pada GML04 yaitu 1,019 mg/L.hari dan laju reaerasi terendah pada GML03 yaitu 0,038 mg/L.hari. GML04 memiliki laju reaerasi tertinggi disebabkan oleh tingginya konstanta reaerasi yaitu 5,888/hari. Tingginya konstanta reaerasi pada GML04 dikarenakan kecepatan aliran tertinggi $0,380 \mathrm{~m} /$ detik dan kedalaman sungai paling dangkal 0,68 m. Menurut Langbein dan Durum (1997), kecepatan aliran dan kedalaman badan air merupakan faktor signifikan yang berpengaruh terhadap laju reaerasi. Sedangkan, GML03 memiliki laju reaerasi terendah disebabkan oleh konsentrasi defisit oksigen yang rendah yaitu 0,009 $\mathrm{mg} / \mathrm{L}$, meskipun konstanta reaerasi dari GML03 cukup tinggi.

\section{KESIMPULAN}

Hasil penelitian menunjukkan bahwa Kualitas air Sungai Bedadung memenuhi kriteria mutu air kelas III berdasarkan Peraturan Pemerintah Republik Indonesia Nomor 82 Tahun 2001 tentang Pengelolaan Kualitas Air dan Pengendalian Pencemaran Air. Sungai Bedadung segmen Desa Gumelar memiliki rata-rata nilai DO yaitu $7,62 \mathrm{mg} / \mathrm{L}$, laju deoksigenasi (rD) sebesar 0,036 mg/L. hari dan laju reaerasi (rR) sebesar 0,046 mg/L.hari. Lebih tingginya rR dibandingkan rD menunjukkan bahwa penambahan oksigen terlarut lebih besar dibandingkan pengurangan oksigen terlarut di dalam perairan sehingga purifikasi alami sungai dapat berlangsung dengan baik. Kondisi ini perlu dipertanahankan bahkan ditingkatkan dengan melakukan sosialisasi kepada masyarakat dan mengajak peran serta masyarakat dalam menjaga kualitas air. Dari hasil penelitian ini perlu dilakukan penelitian lanjutan yaitu menghitung daya tampung sungai Bedadung segmen Desa Gumelar agar dapat diketahui kemampuan daya tampung sungai tersebut dalam menerima beban pencemaran.

\section{UCAPAN TERIMA KASIH}

Ucapan terima kasih kami sampaikan kepada DRPM Ristek Dikti yang telah memberikan kesempatan dan support kepada tim peneliti dalam melaksanakan penelitian ini.

\section{KONFLIK KEPENTINGAN}

Penulis menyatakan bahwa artikel ini asli, belum pernah dipublikasikan, dan bebas dari konflik kepentingan.

\section{DAFTAR PUSTAKA}

Agustiningsih, A. (2012). Analisis Kualitas Air dan Strategi Pengendalian Pencemaran Air Sungai Blukar Kabupaten Kendal. Tesis. Universitas Diponogoro. https://ejournal. undip.ac.id/index.php/presipitasi/article/view/4928.

Alaerts, G. dan Santika, S. S. (1987). Metode Penelitian Air. Surabaya: Usaha Nasional.

Arbie, R. R., W. D. Nugraha, dan Sudarsono. (2015). Studi Kemampuan Self Purification pada Sungai Progo Ditinjau dari Parameter Organik DO dan BOD (Point Source: 
Limbah Sentra Tahu Tuksono, Kecamatan Sentolo, Kabupaten Kulon Progo, Provinsi D.I. Yogyakarta). Jurnal Teknik Lingkungan. 4(3): 1-15. https://ejournal3. undip.ac.id/index.php/tlingkungan/article/view/9138.

Fachrul, M. F., Hendrawan, D., dan Prasetyo, F. (2011). Kajian Laju Pemurnian Sungai Cipinang Bagian Hulu Berdasarkan Parameter DO dan BOD. Jurnal Teknik Lingkungan, FALTL. Universitas Trisakti. 5(6): 215-220.

http://www.trijurnal.lemlit.trisakti.ac.id/index.php/ urbanenvirotech/article/view/696.

Keputusan Menteri Negara Lingkungan Hidup Nomor 110 Tahun 2003. Pedoman Penetapan Daya Tampung Beban Pencemaran Air pada Sumber Air. 27 Juni 2003. Menteri Negara Lingkungan Hidup. Jakarta: Deputi 1 MENLH Bidang Kebijakan dan Kelembagaan Lingkungan Hidup.

Langbein, W. B. dan W. H. Durum. (1967). The Aeration Capacity of Streams. Washington DC: United States Geological Survey.

Mahyudin, Soemarno, dan T. B. Prayogo. (2015). Analisis Kualitas Air dan Strategi Pengendalian Pencemaran Air Sungai Metro di Kota Kepanjen Kabupaten Malang. Jurnal Pembangunan dan Alam Lestari. Universitas Brawijaya. 6(2):107.

http://jpal.ub.ac.id/index.php/jpal/article/view/193.

Peraturan Menteri Negara Lingkungan Hidup Nomor 01 Tahun 2010. Tata Laksana Pengendalian dan Pencemaran Air. 14 Januari 2010. Jakarta: Menteri Negara Lingkungan Hidup.

Peraturan Pemerintah Republik Indonesia Nomor 38 Tahun 2011. Sungai. Tambahan Lembaran Negara Republik Indonesia Nomor 5230. Jakarta: Kementerian Sekretariat Negara RI.

Peraturan Pemerintah Republik Indonesia Nomor 82 Tahun 2001. Pengelolaan Kualitas air dan Pengendalian Pencemaran Air. 14 Desember 2001. Jakarta: Kementerian Sekretariat Negara RI.
Rahayu S., Widodo RH., Noordwijk MV., Suryadi I., Verbist B. (2009). Monitoring Air Di Daerah Alirn Sungai. Bogor: World Agroforestry Centre - Southeast Asia Regional Office.

Ramadhani, N. S., R. Purnaiki, dan K. P. Utomo. (2013). Analisis Sebaran Oksigen Terlarut Saluran Sungai Jawi. Jurnal Teknologi Lingkungan Lahan Basah. 1(1): 3.

http://jurnal.untan.ac.id/index.php/jmtluntan/article/ view/2110.

Razif, M. (1994). Penentuan Konstanta laju Kecepatan Deoksigenasi, Reaerasi dan Sedimentasi Disepanjang Sungai Dengan Simulasi Komputer. Majalah IPTEK ITS. 5(1): $79-89$.

http://personal.its.ac.id/show_publikasi.php?id=4341.

Salmin. (2005). Oksigen Terlarut (DO) dan Kebutuhan Oksigen Biologi (BOD) sebagai Salah Satu Indikator untuk Menentukan Kualitas Perairan. Jurnal Oseana. 30(3): 21-26. http://oseanografi.lipi.go.id/dokumen/oseana_ xxx(3)21-26.pdf.

Santoso, B., K. Hedrijanto, A. Rahmawati, R. Jannah, dan M. R. Tyas. (2013). Model Intervensi Pengelolaan Daerah Aliran Sungai (DAS) (Community Based Action Research Pada Masyarakat Di Daerah Aliran Sungai Bedadung Kabupaten Jember. Jember: Lemlit UNEJ.

Streeter, H. W. dan E. B. Phelps. (1925). A Study of The Pollution and Natural Purification of Ohio River. Washington DC: US Public Health Service.

Triatmodjo, B. (2013). Hidrologi Terapan. Yogyakarta: Beta Offset Yogyakarta.

Wiwoho. (2005). Model Identifikasi Daya Tampung Beban Cemaran Sungai dengan QUAL2E. Tesis. Universitas Diponegoro. http://eprints.undip.ac.id/11485/. 